\title{
ASSESSMENTS OF ANTIOXIDANT CONTENT AND THE ANTI-CARCINOGENIC EFFECT OF EXTRACTS OF SOLANUM ROSTRATUM DUNAL IN HUMAN CANCER CELLS
}

\author{
MARÍA DEL CARMEN VALADEZ-VEGA ${ }^{1 *}$, JEANNETT A. IZQUIERDO-VEGA', \\ MANUEL SÁNCHEZ-GUTIÉRREZ1', JOSÉ ROBERTO VILLAGÓMEZ-IBARRA², \\ EDUARDO OSIRIS MADRIGAL SANTILLÁN''ㅗ' JOSÉ A. MORALES-GONZÁLEZ ${ }^{3}$, \\ MIRANDELI BAUTISTA-ÁVILA' ${ }^{1}$ and LAURA GARCÍA-VELAZCO ${ }^{1}$
}

'Área Académica de Medicina, Instituto de Ciencias de la Salud, Universidad Autónoma del Estado de Hidalgo, Ex-Hacienda de la Concepción S/N, Tilcuautla, 42160 San Agustín Tlaxiaca, Hidalgo, México 2ª́rea Académica de Química, Instituto de Ciencias Básicas e Ingeniería, Universidad Autónoma del Estado de Hidalgo, Ciudad del conocimiento, Mineral de la Reforma, 42184 Hidalgo, México

${ }^{3}$ Laboratorio Medicina de Conservación, Escuela Superior de Medicina, Instituto Politécnico Nacional, Plan de San Luis y Díaz Mirón s/n, Unidad Casco de Santo Tomas, México D.F. 11340, México

\begin{abstract}
In Mexico, Solanum rostratum has been employed for the treatment of several diseases, including uterine cancer. The aim of this study was to evaluate antioxidant and anti-carcinogenic activities of S. rostratum Dunal extracts on the breast and uterine cancer cell lines, MDA and SiHa, respectively. The methanolic, ethyl acetate, and hexane extracts of the aerial parts of $S$. rostratum were tested for phenol concentration, antioxidant activity, and anti-carcinogenic effects. The leaves extracts showed the highest content of phenols; however, the flower-fruits extracts showed higher scavenging activity. On the other hand, ethyl acetate extracts exhibited the highest anti-carcinogenic effects on these cells, while methanolic extracts showed the least effects. The results of this work indicate that $S$. rostratum is a promising source of antioxidants, and the extracts exert dose-dependent anti-carcinogenic effects on both cell lines.
\end{abstract}

Keywords: cytotoxic, antioxidant, Solanum rostratum, MDA cell line, SiHa cell line

Cancer includes a group of more than 100 different types of diseases characterized by the accelerated and disorderly growth of abnormal cells. Cancer is a major worldwide public health problem. According to the International Agency for Research on Cancer (IARC), cancer increased to 18.1 million new cases and 9.6 million cancer deaths in 2018 (1). Historically, natural products have been used since ancient times and in folklore for treatment of many diseases (2). Traditional medicine is known the sum total of the knowledge, skills, and practices based on the theories and experiences indigenous to different cultures used in the maintenance of health and for the prevention, diagnosis, improvement, and/or treatment of illness (3). Plants have comprised the basis of traditional medicine systems and their use by the peoples of many cultures has been widely documented. The World Health Organization has estimated that approximately $80 \%$ of the world's inhabitants mainly employ traditional medicine for their primary healthcare (4). Currently, the use of medicinal plants to treat and prevent various types of cancer has experienced a breakthrough. Along with the cancer treatment ranging from surgery and radiation to chemotherapy or immunotherapy, millions of people seek additional options such as complementary and alternative medicine.

In traditional Mexican folk medicine, Solanum rostratum has been used for years to treat kidney disorders, stomachache, and digestive disorders and with the use of the infusion of the leaves as a purgative. A tea prepared with the plant's flowers is rec-

* Corresponding author: e-mail: marynavaladez@hotmail.com 
ommended for stomach pain and cough, and the infusion of the leaves is used for chronic coughs. Water-cooling of the plant's branch applied in baths is recommended as an antirheumatic. The aerial part of the plant is utilized in preparations of infusions with which vaginal washes are made to control vaginal fluids, disinfect genitals, and as an auxiliary in the treatment on uterine cancer. This plant is also known as buffalo burr, (5) Kansas thistle, (6) beaked nightshade, sand burr, Colorado burr, and Texas thistle (7). In Mexico, it is known as Mexican thistle, duraznillo, abrojo, mala mujer, hierba del sapo, espinaca del cerro, and mancamula (8). The native range of $S$. rostratum extends from central Mexico to the United States. However, it can now be found in other countries such as China, Russia, Australia, and Europe (9, 10). Unfortunately, few studies have researched the biological action of S. rostratum. Thus, the objective was to evaluate the content of the phenols compounds, the antioxidant activities, and the anti-carcinogenic effects of S. rostratum Dunal extracts on the human malignant cell lines, $\mathrm{SiHa}$ and MDA, using the tetrazolium (MTT) to assay for cell viability.

\section{MATERIALS AND METHODS}

\section{Plant material}

S. rostratum Dunal was collected in the town of Epazoyucan, Hidalgo, Mexico in July 2012, where it grows in the wild. The identification of the plant was done by Professor Manuel González Ledesma. After identification, a plant specimen was deposited in the Herbarium of the Biological Research Centre of the University of the State of Hidalgo. The plant was cleaned, different sections (leaves, stems, and flowers-fruits) were separated, and these were then dried in darkness in special panels at room temperature. The different sections of the plant were stored in hermetically sealed bags and stored until further use.

\section{Extract preparation}

Five-hundred grams of the dried ground leaves, stems, and flowers-fruits were macerated with hexane $(1 \mathrm{~L})$, ethyl acetate $(1 \mathrm{~L})$, and methanol $(1 \mathrm{~L})$ for one week at room temperature. After this period, the extracts were filtered through Whatman no. 1 filter papers and evaporated under reduced pressure to dryness in a rotary evaporator $50^{\circ} \mathrm{C}$. The yield consisted of several components: (1) flowers-fruits (7.8 $\mathrm{g}$ hexane, $33.7 \mathrm{~g}$ ethyl acetate, $47.6 \mathrm{~g}$ methanol); (2) leaves (4.1 $\mathrm{g}$ hexane, $12.7 \mathrm{~g}$ ethyl acetate, $41.5 \mathrm{~g}$ methanol); and (3) stems (2.6 g hexane, 4.5 ethyl acetate, $38.8 \mathrm{~g}$ methanol). The dried extracts were stored at $0^{\circ} \mathrm{C}$ until use.

\section{Antioxidant activity - DPPH}

The free radical scavenging activity of the extract of $S$. rostratum Dunal was evaluated using the stable free radical 1,1-diphenyl-2-picrylhydrazyl $\left(\mathrm{DPPH}^{\bullet}\right)$ according to Morales and Jimenez (11). One-hundred microliters of extracts were mixed with $900 \mu \mathrm{L}$ of a methanolic solution of $0.25 \mathrm{mM}$ $\mathrm{DPPH}^{\bullet}$ (Sigma Aldrich). The mixture was shaken and incubated at room temperature for $30 \mathrm{~min}$. Twohundred microliters were placed into 96-well plates, and the change in optical density at $520 \mathrm{~nm}$ was continuously monitored using a microplate reader (Biotek® Winooski, VT, USA). Trolox was used as the standard. Samples were assayed in six replicates. The percent inhibition was calculated from control using the following equation: Scavenging activity $\%$ $=\left(\left[1-\right.\right.$ Absorbance $\left._{\text {sample }}\right] /\left[\right.$ Absorbance $\left.\left._{\text {control }}\right]\right) \times 10$.

\section{Antioxidant activity - ABTS ${ }^{+}$ \\ Trolox equivalent antioxidant capacity} (TEAC) was estimated as 2,2'-azinobis(3-ethylbenzothiazline-6-sulfonic acid) diammonium salt (ABTS) radical scavenging activity according to the method developed by Re et al. (12). Briefly, ABTS (Sigma Aldrich, St. Louis, MO, USA) was dissolved in water to yield a $7 \mathrm{mM}$ concentration. ABTS radical cation $\left(\mathrm{ABTS}^{\bullet+}\right.$ ) was produced by reacting stock solution with $2.45 \mathrm{mM}$ potassium persulfate (final concentration) and allowing the mixture to stand in the dark at room temperature for 12-16 $\mathrm{h}$. The antioxidant standard was 6-hydroxy-2,5,7,8-tetramethylchroman-2-carboxylic acid (Trolox). A standard calibration curve was constructed for Trolox in ethanol (Sigma Aldrich). $100 \mu \mathrm{L}$ of diluted samples were mixed with $900 \mu \mathrm{L}$ of $\mathrm{ABTS}^{\bullet+}, 200 \mu \mathrm{L}$ of the mix were placed into 96-well plates, and the absorbance at $734 \mathrm{~nm}$ was read after $5 \mathrm{~min}$ in a microplate reader (Biotek ${ }^{\circledR}$, Winooski, VT, USA). Samples were assayed in triplicate, and the results were expressed as mg Trolox equivalents per gram (mg TEAC/g).

\section{Antioxidant activity - total phenolic content}

Total polyphenols were determined spectrophotometrically using the Folin Ciocalteu method described by Singleton and Rossi (13). Total phenolics of the extract were calculated and reported as gallic acid equivalents. All samples were prepared and measured in triplicate. Gallic acid was used as the standard. 


\section{Antioxidant activity - tannins content}

Tannins were determined according to the modified vanillin- $\mathrm{HCl}$ method of Price et al. (14) using (+)-catechin (Sigma Chemical Co, St Louis, MO, USA) as standard. Tannin content was expressed as $\mathrm{mg}$ equivalents of catechin (CE) per gram of sample $(\mathrm{mg} \mathrm{CE} / \mathrm{g})$.

\section{Cytotoxicity assay}

The cytotoxicity assay was carried out as described by Valadez-Vega et al. (15) using the human malignant cells lines, MDA-MB 231 (breast adenocarcinoma cells) and $\mathrm{SiHa}$ (cervix squamous cancer cells), which were obtained from American Type Culture Collection (ATCC, Rockville, MD USA). The cells were grown in Dulbecco's modified Eagle's medium (DMEM) (Gibco, Grand Island, NY, USA) with $10 \%$ fetal bovine serum (FBS) (Gibco) in a $\mathrm{CO}_{2}$ water-jacketed incubator (Nuaire, Plymouth, MN, USA) at $37^{\circ} \mathrm{C}$ in humidified atmosphere of $5 \% \mathrm{CO}_{2}$ and $95 \%$ air.

\section{Cell viability assay}

The tetrazolium dye colorimetric test (3-(4,5diMethylthiazol-2-yl)-2-5-diphenyltetrazolium bromide (MTT) was used to determine the cell line viabilities. The MTT assay is based on the ability of functional mitochondria to catalyze the reduction of (3-(4,5-dimethylthiazol-2-yl)-2-5-diphenyltetrazolium bromide to insoluble formazan, the concentration of which can be measured spectrophotometrically (16). SiHa and MDA cell lines were first cultured in 96-well microplates $\left(15.0 \times 10^{3}\right.$ cells/well $)$ in DMEM for $24 \mathrm{~h}$, washed twice using phosphate- buffered saline (PBS), and treated with different extract concentrations. After a $24 \mathrm{~h}$ incubation, the extract was eliminated, the cells were washed with PBS, MTT reagent $(5 \mathrm{mg} / \mathrm{mL})$ was added to each well, and the plate was incubated at $37^{\circ} \mathrm{C}$ for an additional $3 \mathrm{~h}$. The media were then removed, and the intracellular water-insoluble dark formazan product was dissolved in dimethyl sulfoxide (DMSO). The absorbance of each well was then measured at $540 \mathrm{~nm}$, and the percentage of cell viability was calculated.

\section{Statistical analysis}

Experimental results are expressed as mean \pm SEM. All measurements were replicated three times. The data were analyzed with an analysis of variance (ANOVA) $(p<0.05)$ followed by the Tukey posthoc test for multiple comparisons using the Statgraphics Centurion 18 software. $\mathrm{IC}_{50}$ values were calculated from the linear regression analysis.

\section{RESULTS}

\section{Antioxidant capacity - DPPH $^{\bullet}$ and ABTS $^{\bullet+}$}

Antioxidant activity of $S$. rostratum Dunal extract was evaluated using two free radical scavenging assays, $\mathrm{DPPH}^{\bullet}$ and $\mathrm{ABTS}^{\bullet+}$ (Figure 1 and Table 1). The results showed that different antioxidant potentials existed in all of the extracts. The flowers-fruit extracts were found to be the richest source of antioxidant of all of the samples analyzed, ranging between $88.59 \%$ to $92.63 \%$ of scavenging activity. This result was similar in both assays; however, the activity was lower in the $\mathrm{DPPH}^{\bullet}$ over the

Table 1. Total phenols, Tannins, DPPH $\bullet$, and $\mathrm{ABTS}^{\bullet+}$ antioxidant capacity of Solanum rostratum Dunal.

\begin{tabular}{|c|c|c|c|c|c|}
\hline \multirow{3}{*}{ Disolvent } & & Total phenols & Tannins & DPPH" $^{\prime}$ & ABTS $^{\text {o+ }}$ \\
\cline { 3 - 6 } & & $\mathrm{mg} \mathrm{GAE} / \mathrm{g}$ & $\mathrm{mg} \mathrm{CE} / \mathrm{g}$ & $\mathrm{mg} \mathrm{TEAC/g}$ & $\mathrm{mg} \mathrm{TEAC/g}$ \\
\hline \multirow{3}{*}{ Methanol } & Stems & $15.26 \pm 0.36^{*}$ & $80.65 \pm 2.07^{*}$ & $2.666 \pm 0.692^{*}$ & $15.02 \pm 0.322^{*}$ \\
\cline { 2 - 6 } & Flower-fruits & $26.76 \pm 1.38^{*}$ & $107.64 \pm 4.32^{*}$ & $12.806 \pm 0.323^{*}$ & $30.34 \pm 0.039$ \\
\cline { 2 - 6 } & leaves & $35.25 \pm 1.62^{*}$ & $130.74 \pm 13.01^{*}$ & $10.198 \pm 1.607^{*}$ & $29.53 \pm 0.016$ \\
\hline \multirow{3}{*}{ Ethyl acetate } & Stems & $40.43 \pm 0.47$ & $161.86 \pm 2.56^{*}$ & $4.672 \pm 0.427$ & $26.20 \pm 0.028^{*}$ \\
\cline { 2 - 6 } & Flower-fruits & $43.55 \pm 2.37$ & $145.69 \pm 9.07^{*}$ & $12.193 \pm 2.32^{*}$ & $30.65 \pm 0.008^{*}$ \\
\cline { 2 - 6 } & leaves & $36.51 \pm 3.60$ & $157.97 \pm 2.0$ & $2.962 \pm 0.648$ & $19.91 \pm 0.071^{*}$ \\
\hline \multirow{3}{*}{ Hexane } & Stems & $7.44 \pm 0.51^{*}$ & $58.16 \pm 4.78^{*}$ & $6.698 \pm 0.308$ & $2.47 \pm 0.064^{*}$ \\
\cline { 2 - 6 } & Flower-fruits & $14.09 \pm 0.78^{*}$ & $197.84 \pm 15.8 * 8$ & $6.869 \pm 0.162$ & $29.29 \pm 0.008^{*}$ \\
\cline { 2 - 6 } & leaves & $31.62 \pm 0.77^{*}$ & $247.81 \pm 2.61 *$ & $2.737 \pm 0.461^{*}$ & $17.55 \pm 0.054^{*}$ \\
\hline
\end{tabular}

Total phenols are expressed as GAE; galic acid equivalents; Tannins are expressed are expressed as CE; +Cattechin equivalents and the antioxidant capacity was assayed by trolox equivalent antioxidant capacity (TEAC), ABTS ${ }^{\circ+}$; DPPH". All results are expressed as mean \pm SEM of three independent experiments. Comparison between extracts was done by analysis of variance (ANOVA) followed by the Tukey post-hoc test. For all comparison, statistical significance was assigned at $\mathrm{p}<0.05$ and marked using asterisks $\left({ }^{*}\right)$ 
$\mathrm{ABTS}^{\bullet+}$ assay. On the other hand, it could be observed that the best solvent to extract the antioxidants was methanol as can be seen in Table 1. The highest antioxidant activity values were present in the extracts of stems, flowers, and leaves after using this solvent. The flower-fruit extract in ethyl acetate and methanol presented the highest antioxidant concentrations at $30.65 \pm 0.008$ and $30.34 \pm 0.039 \mathrm{mg}$ $\mathrm{TEAC} / \mathrm{g}$, respectively, in comparison with the lower extract concentrations of these compounds, which was that of stems and hexane at $2.47 \pm 0.064 \mathrm{mg}$ TEAC/g.

\section{Antioxidant capacity - total phenols and tannins compounds}

In the present study, phenolic compounds were found in all of the extracts, regardless of the solvent's polarity, but the greater affinity was found in solvents with intermediate polarity. The content of total phenolic and tannin compound is shown in Table 1 . The ethyl acetate extracts were those with the highest concentration of phenols, which were the flower-fruit extracts. These extracts presented a higher content (43.55 mg GAE/g); in contrast, the hexane extracts showed a lower phenol content, in which the stem extract ( $7.44 \mathrm{mg} \mathrm{GAE} / \mathrm{g})$ was the one that showed the lowest content in all of the extracts. In relation to the tannin content, the leaf extract in all of the solvents showed higher concentrations (130.74-247.8 mg CE/g). Ethyl acetate and hexane were the best solvents for extracting these compounds; conversely, the extract of stems in hexane showed the lowest concentration of these compounds at $58.16 \pm 4.78 \mathrm{mg} \mathrm{CE} / \mathrm{g}$.

\section{Anti-cancer activity}

Anti-carcinogenic results in MDA cells are depicted in Figure 2. We can observe that in the extracts obtained with methanol, the three parts of the plant demonstrated a dose-dependent effect, significantly decreasing cell viability by increasing the extract concentrations. The decline in viability was more drastic in the leaf extract with a mean inhibitory dose $\left(\mathrm{ID}_{50}\right)$ of $440 \mu \mathrm{g} / \mathrm{mL}$, while in the case of stems and flower-fruit extracts, the $\mathrm{ID}_{50}$ were 3,080 and $710 \mu \mathrm{g} / \mathrm{mL}$, respectively (Figure 2A). The results for ethyl acetate extracts are presented in Figure 2B, indicating that MDA cells also possess a dose-dependent anti-carcinogenic effect, which caused a considerable decrease in cell viability with increasing extract concentrations. The anti-carcinogenic effect in the leaf extract was superior with an $\mathrm{ID}_{50}$ of $107 \mu \mathrm{g} / \mathrm{mL}$, while for the stem and extract these effects was $128 \mu \mathrm{g} / \mathrm{mL}$ and $460 \mu \mathrm{g} / \mathrm{mL}$, respectively. Hexane extracts (Figure 2C) exhibited a tendency to diminish cell viability in the three parts of the analyzed plant extracts, but the stem extracts presented a lower $\mathrm{ID}_{50}$ with $250 \mu \mathrm{g} / \mathrm{mL}$ followed by the flower-fruit extract $(275 \mu \mathrm{g} / \mathrm{mL})$, and cell viability was higher for the leaf extracts $(382 \mu \mathrm{g} / \mathrm{mL})$. As

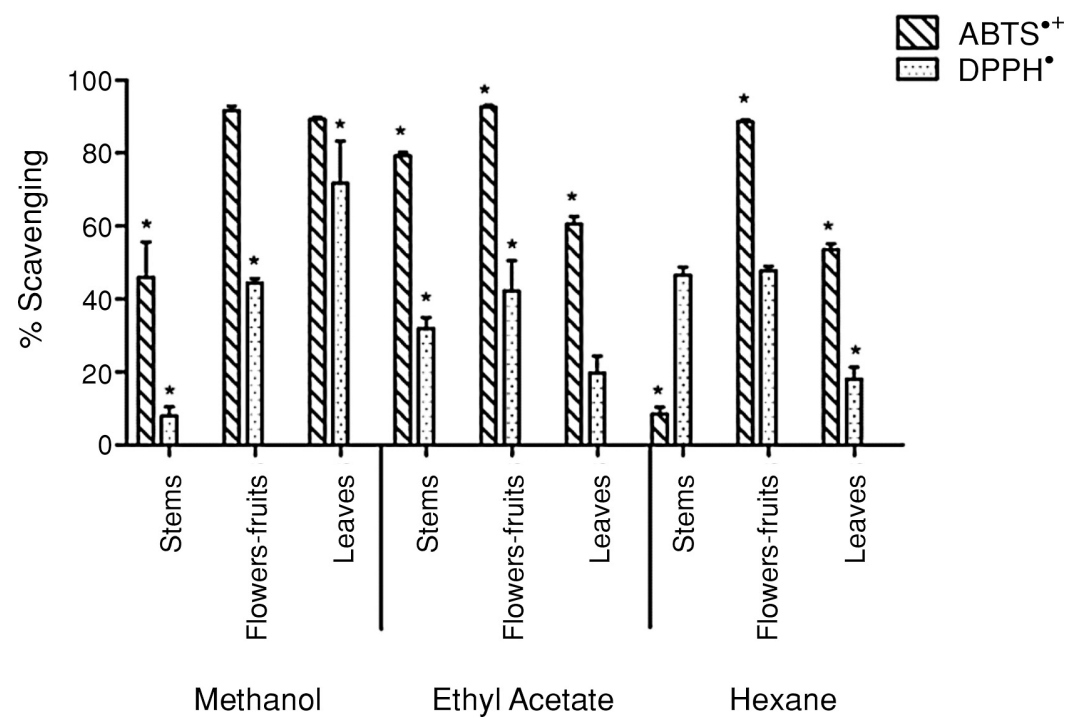

Figure 1. Antioxidant activity of methanol, ethyl acetate and hexane extract of Solanum rostratum Dunal. The antioxidant capacity was assayed by Trolox equivalents antioxidant capacity (TEAC). Results represent the mean \pm SEM values of triplicate experiments. *Indicates statistical differences between plant sections $(\mathrm{p}<0.05)$ 
can be observed, the methanolic extracts exhibited the lowest inhibitory effect on the cell viability of MDA cells followed by hexane, whereas ethyl acetate extracts demonstrated the highest cytotoxic effect on the three tested plant parts. On the other hand, the leaf extract in ethyl acetate presented the highest inhibition in cell viability in all cases, indicating a major anti-carcinogenic effect on this cell line, while the methanolic extract of stems was that which showed the least anti-carcinogenic effect on these cells.

In the case of the SiHa cell line, the results of the methanol extract are illustrated in Figure 3A, which indicate great variability in the response of the three extracts analyzed. The leaf extract is the one that showed better anticarcinogenic effects with an $\mathrm{ID}_{50}$ of $160 \mu \mathrm{g} / \mathrm{mL}$ followed by the stem extracts with an $\mathrm{ID}_{50}$ of $940 \mu \mathrm{g} / \mathrm{mL}$, while the flower-fruit extract exhibited the least anti-carcinogenic effects with an $\mathrm{ID}_{50}$ of $9,600 \mu \mathrm{g} / \mathrm{mL}$. As shown in Figure $3 \mathrm{~B}$, the results obtained while using ethyl acetate for the stem extract demonstrated the greatest anti-carcinogenic effects with an $\mathrm{ID}_{50}$ of $52 \mu \mathrm{g} / \mathrm{mL}$; conversely, the flower-fruit extract exhibited the least cytotoxic effects with an $\mathrm{ID}_{50}=188 \mu \mathrm{g} / \mathrm{mL}$, whereas the $\mathrm{ID}_{50}$ of the leaves extract was $115 \mu \mathrm{g} / \mathrm{mL}$. The anti-carcinogenicity of hexane extracts on $\mathrm{SiHa}$ cells is shown in Figure 3C. The results indicated that leaf and stem extracts showed similar behavior in their cytotoxic actions with an ID $_{5}$ of 395 and $365 \mu \mathrm{g} / \mathrm{mL}$, respectively. In contrast, the flower-fruit extract presented the lowest $\operatorname{ID}_{50}(205 \mu \mathrm{g} / \mathrm{mL})$.

\section{DISCUSSION}

Antioxidant activities of $S$. rostratum Dunal extracts were evaluated using the free radical scavenging assays, $\mathrm{DPPH}^{\bullet}$ and $\mathrm{ABTS}^{\bullet+}$. The $\mathrm{DPPH}^{\bullet}$ scavenger assay has been commonly employed to measure the antioxidant activity of many natural compounds. $\mathrm{DPPH}^{\bullet}$ is a stable free radical resulting from the delocalization of the spare electron over the molecule. When $\mathrm{DPPH}^{\bullet}$ is mixed with a substance donor of the hydrogen atom, its reduced form is produced (DPPH-H), in which it loses the violet color and forms a yellow color $(17,18)$. On the other hand, the ABTS $^{\bullet+}$ assay involves the direct production of the blue-green $\mathrm{ABTS}^{\bullet+}$ through the reaction between $\mathrm{ABTS}^{\bullet+}$ and potassium persulfate. The addition of antioxidants to the radical cation reduces it to $\mathrm{ABTS}^{\bullet+}$. Depending on the antioxidant's activity, concentration, and time of exposure, the addition of antioxidants to the radical cation reduces it to $\operatorname{ABTS}^{\bullet+}$ (12). The antioxidant activity of the S. ros- tratum Dunal extracts varied, depending on the part of the plant and solvent used and was greater in the flower-fruit extracts than in the other sections of the plant; it was also observed that the best solvent to extract antioxidant compounds was ethyl acetate. The results showed that $S$. rostratum Dunal can be considered a good source of antioxidants, with strong free radical scavenging activity.

The antioxidant effect observed may be due in part to the presence of polyphenolic compounds and that there is a correlation between the concentration of total phenols and the antioxidant activity as reported by Javanmardi et al. (19). However, this activity is not only due to antioxidants compounds since as has been reported for other plants since there are other types of secondary metabolites such as some carotenoids, flavonoids, saponins, and alkaloids, which have antioxidant activity (16). Due to the diversity and the complexity of the phenols mixture in the extracts, the characterization of these compounds becomes complicated. It is known that each plant extract has a different phenol content and that the antioxidant activity of each varies in its antioxidant activity (14). The phenols' antioxidant activities are due to their redox properties, acting as reducing agents, hydrogen donors, and singlet oxygen quenchers (20). These activities may be the reason why the antioxidants found in $S$. rostratum can scavenge the free radicals formed by $\operatorname{ABTS}^{\bullet+}$ and $\mathrm{DPPH}^{\circ}$, thus causing a decrease in their oxidative activity as demonstrated in the results obtained from the plant extracts. Likewise, for other Solanaceae such as $S$. nigrum, which presents a remarkable antioxidant activity in the $\mathrm{DPPH}^{\bullet}$ test $(21,22)$, varies in its activity depending on the type of solvent used for the preparation of the extracts and the part of the plant evaluated. On the other hand, for S. melongena, S. crispum, and S. trilobatum, it has been reported that they present compounds capable of sequestering free radicals in vitro (23-26).

In the extracts, total phenols and tannins were found in important concentrations, with greater abundance in the three extracts of ethyl acetate although also were found in lower concentration in the extracts of methanol and hexane. Tannins and phenols have been found in several Solanaceae species, such as S. xanthocarpum, S. nigrum Linn, and $S$. trilobatum, and its presence has been linked to the medicinal and therapeutic effects in diseases such as anti-ulcerogenic, anti-microbial, bronchodilator, anti-inflammatory, inductor of some human cancer cells apoptosis, and cycle cell arrest (21, 27-30).

Our results indicated that the ethyl acetate extracts were those that showed the highest anti-car- 

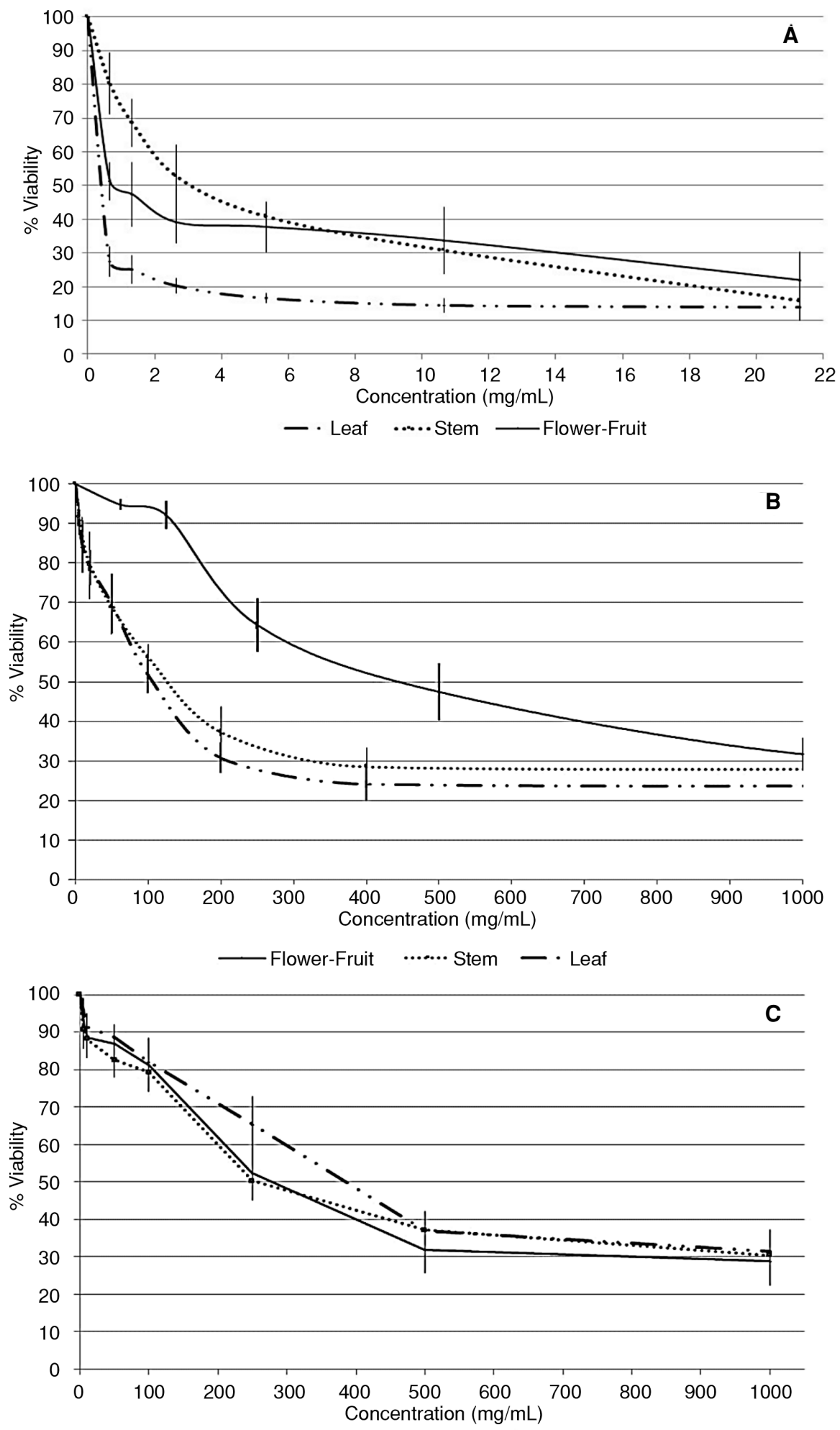

— Flower-Fruit ${ }^{2}$....... Stem —. Leaf

Figure 2. Anti-carcinogenic effect of Solanum rostratum Dunal on the MDA cell line. Methanolic extract (A), ethyl acetate extract (B), and hexane extract (C) of Solanum rostratum Dunal on the MDA cell line after $24 \mathrm{~h}$ of exposure employing the MTT cell assay. All values are expressed as mean \pm SEM of the three independent experiments 

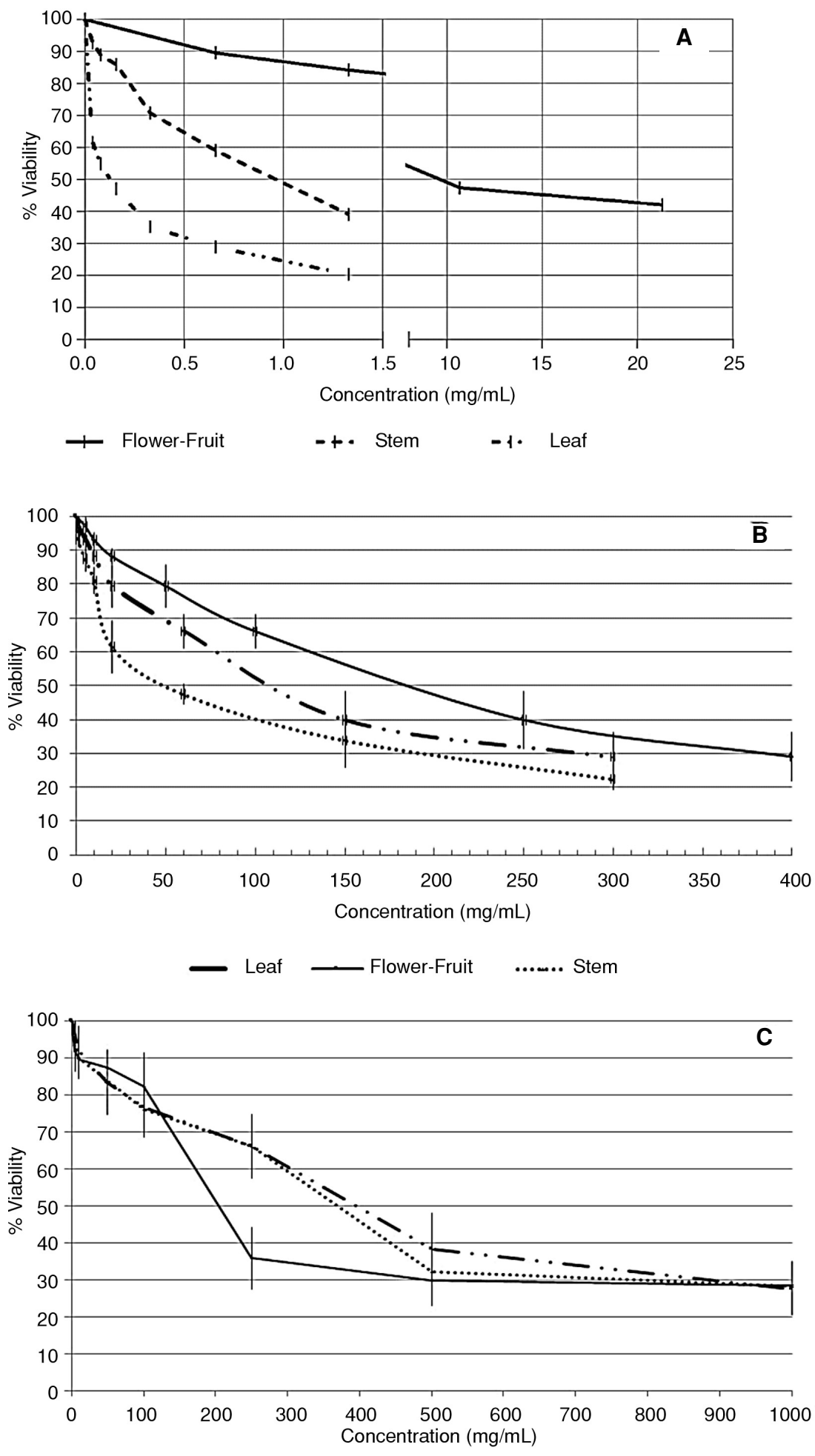

- Flower-Fruit $\quad-$ Leaf $\quad \cdots \cdots \cdot$ Stem

Figure 3. Anti-carcinogenic effect of Solanum rostratum Dunal on the SiHa cell line. Methanolic extract (A), ethyl acetate extract (B), and hexane extract (C) of Solanum rostratum Dunal on the SiHa cell line after $24 \mathrm{~h}$ of exposure employing the MTT cell assay. All values are expressed as mean \pm SEM of the three independent experiments 
cinogenic effect in both cell lines with the stem extract showing the highest effects on both cell lines. This effect was statistically significant compared with the other extracts. In the case of leaves, the ethyl acetate extract showed the highest anti-carcinogenic effect on both lines, but in MDA (31) cells, the cytotoxic effects were higher. With regard to the flower-fruit extracts, the ethyl acetate extract exhibited the highest effect in the SiHa cell line. In the hexane extracts, the results were very similar in both cell lines with the highest and lowest anti-carcinogenic effects in the SiHa cell line in fruit and leaf extracts, respectively. There are few published studies on the biological effects of $S$. rostratum extracts. The $S$. rostratum ethanolic extract reduced the viability of the Hela cell line, and the damage was time- and dose-dependent (32). Some researchers have demonstrated important compounds present in $S$. rostratum, including methyl-protodioscin that was identified in the methanol-chloroform-extract of the aerial parts $(33,34)$. Methyl-protodioscin is a bioactive natural compound that has numerous pharmacological activities, including those related to antiinflammatory and anticancer activities. The antiproliferative effects have been shown to involve cell cycle arrest and apoptosis induction in several cancer cell lines $(35,36)$. Flavonoids and saponins are the most common isolated compounds that have been found in the Chinese species $S$. rostratum (34); however, Chinese researchers have not even reported the biological effect of these compounds. Thus, it is also necessary to evaluate their toxicological and anti-carcinogenic effects.

Several cytotoxic and anti-carcinogenic studies have been performed with several Solanaceae genera. Extracts of S. nigrum fruits, leaves, and stems exhibited anticancer activities on different human cancer cell lines and also cytotoxic activity on normal 3T3 NIH mouse embryo fibroblasts and rat Wistar hepatocytes cell lines (37-46). Each cell line has shown important differences in anticarcinogenic activity due to the polarity difference of the solvents and the extraction methods. Other Solanum species (S. paniculatum, S. pseudocapsicum) extracts prepared with high polarity solvents were tested in cell lines, and it was found that leaves and flower-fruit extracts contain alkaloids that induce mutagenic and cytotoxic effects and antitumor activities against Dalton's lymphoma ascites tumor in mice $(47,48)$. The anti-carcinogenic effects were attributed to compounds such as saponins, triterpenes, oligosaccharides, glycoproteins, and/or glycoalkaloids via inhibition of the transcription factors that play an important role in tumor progression $(38,39,49)$.
Furthermore, it has been demonstrated that the reduction of HepG2 and U14 tumor cells in tumorbearing mice was due to that the extract caused cell cycle arrest in the G2 and G0/G1 phases and growth inhibition via apoptosis induction (46). Likewise, S. lyratum extract has demonstrated cytotoxicity by inducing $\mathrm{S}$ phase arrest in human colon adenocarcinoma cell line (50), and its antitumor activity improved the natural killer (NK) cell activity of Lewis tumor-bearing mice, increasing the number of CD4 cells in tumor-bearing mice and significantly increasing the survival rate of tumor-bearing mice (51). Extracts of S. jamesii tuber exhibited antiproliferative activity toward the human cancer cells, HT-29 and LNCaP (52), and S. nudum was proven to be cytotoxic toward U937 and HepG2 cells (53). Alkaloids extracted from S. pseudocapsicum indicated cytotoxicity toward Hep-G2, HT-29, RD-228, B16F10, A-549, and Vero cell lines (54), and solamargine and solasonine alkaloids extracted from S. lycocarpum indicated antiproliferative activity against B16F10, HT29, MCF-7, HeLa, HepG2, MO59J, U343, and U251 cells (55). Another study with solamargine from $S$. incanum indicated that this compound exerts a higher cytotoxic effect in comparison with cisplatin, methotrexate, 5-fluorouracil, epirubicin, and cyclophosphamide against human breast cancer cells, and the effect was exerted by inducing cellular apoptosis that resulted in the release of mitochondrial cytochrome $\mathrm{c}$ and activation of caspases-8, -9 , and -3 in these cells, indicating that solamargine triggered extrinsic and intrinsic apoptotic pathways of breast cancer cells (56).

Studies have shown that the polyphenolic compounds present in extracts of S. nigrum show anticarcinogenic activity in some cell types, as in the case of HepG2, the cells being arrested in the G2/M phase of the cell cycle (57). Nawab et al., (29) demonstrated that an extract of this same plant, rich in phenols, is able to inhibit proliferation and accelerate apoptosis in PZ-HPV-7CA-HPV-10 cells. In the present study it is shown that there is a correlation between the content of phenols and the cytotoxic action of the extracts; since the extracts richest in phenolic compounds were those that showed greater cytotoxic action in both cell lines.

It has been demonstrated that glycoalkaloids such as solasonine, $\beta 1$-solasonine, solamargine, and solanigroside exert a cytotoxic effect on MGC-803 cells and that their cytotoxic action may be associated with a decrease of the p53 mutation and activation of caspase-3 inducing apoptosis (58). In addition, in HeLa cells, it was proved that alkaloids isolated from the plant are capable of inhibiting cell 
growth (59). Steroidal glycosides (spirostane, spirosolane, furostane, and pregnane) isolated from Solanum showed cytotoxic activity against human lung cancer (PC-12) and human colon cancer (HCT-116) cell lines, and it was demonstrated that $\beta$-lycotetraosyl spirostanol without the functional oxygen groups was the most effective against PC12 and HCT-116 cell lines, indicating that galactotigonin showed the strongest activity (60). Additionally, several studies have indicated that steroidal alkaloids (solanocapsine, solacasine, solacapine, episolacapine, isosolacapine, and O-methyl solanocapsine) from Solanum species contribute toward cytotoxic activity via cytotoxic and antitumor properties (61).

As previously indicated, extracts of various species of Solanum have the ability to inhibit the proliferation of a variety of human malignant cells, which agrees with this study's results because we have shown that extracts of $S$. rostratum possess the capability to inhibit proliferation of cell lines $\mathrm{SiHa}$ and MDA due to their cytotoxic effects. Likewise, these results lead us to suggest that the anti-carcinogenic effect of the extracts tested in this study depends on the cell line studied, the solvent used for the extracts, as well as the part of the plant used. However, it is noteworthy that more studies are required to separate and identify the bioactive compounds present in the extracts and the mechanisms of action of the anti-carcinogenic effects in order to identify the compounds and evaluate if the whole mixture or individual constituents are responsible for the biological effect on these cell lines and other biological functions in general.

\section{CONCLUSION}

The results of this study showed that $S$. rostratum is a promising source of antioxidant compounds; additionally, the extracts exerted dosedependent anticarcinogenic effects on MDA and SiHa cell lines and also showed that the anticarcinogenic effects depended on the kind of solvent and the selected plant part. Ethyl acetate extracts presented the highest anticarcinogenic effects.

\section{Conflicts of interest}

Authors declare no conflict of interest.

\section{Acknowledgment}

This study was partially supported by PAIUAEH 2015 and PROFOCIE 2016.

\section{REFERENCES}

1. Bray F., Ferlay J., Soerjomataram I., Siegel R. L., Torre L.A. et al.: CA. Cancer J. Clin. (2018).

2. Cortez-Gallardo V., Macedo-Ceja J., Hernández Arroyo M., Arteaga-Aureoles G., Espinosa-Galván D. et al.: Rev. Biomed. 15, 123 (2004).

3. Che C.T., George V., Ijinu T.P., Pushpangadan P., Andrae-Marobela K.: Traditional Medicine: Pharmacognosy: Fundamentals, Applications and Strategy. p. 15 Elsevier Inc. (2017).

4. 2014-2023 WHO Traditional Medicine Strategy (2013).

5. Alex J.F., Cayouette R., Mulligan G.A.: Common and botanical names of weeds in Canada (1980).

6. Gray A., Gray A.: Manual of the botany of the northern United States, GP Putman \& Company (1856).

7. Muenscher W.C.: Weeds. 2nd Ed., pp. 560, The Macmillan Company, New York 1955.

8. Del Vitto L.A., Petenatti E.M.: Rev. FCA UNCUYO 47, 109 (2015).

9. Lin Y.T.D.: Acta Phytotaxon. Sin. 45, 675 (2007).

10. Fedorov A.A., Bobrov A.E.: Flora of Russia: the European part and bordering regions., p. 238, The University of Michigan 1999.

11. Morales F.J., Jiménez-Pérez S.: Food Chem. 72, 119 (2001).

12. Re R., Pellegrini N., Proteggente A., Pannala A., Yang M. et al.: Free Radic. Biol. Med. 26, 1231 (1999).

13. Singlenton V.L., Rossi J.A.: Am. J. Enol. Vitic. 16, 144 (1965).

14. Price M.L., Van Scoyoc S., Butler L.G.: J. Agric. Food Chem. 26, 1214 (1978).

15. Valadez-Vega C., Alvarez-Manilla G., RiverónNegrete L., García-Carrancá A., MoralesGonzález J.A. et al.: Molecules 16, 2107 (2011).

16. Hansen M.B., Nielsen S.E., Berg K.: J. Immunol. Methods 119, 203 (1989).

17. Kedare S.B., Singh R.P.: J. Food Sci. Technol. 48, 412 (2011).

18. Polu P.R., Nayanbhirama U., Khan S., Maheswari R.: BMC Complement. Altern. Med. 17, 457 (2017).

19. Javanmardi J., Stushnoff C., Locke E., Vivanco J.: Food Chem. 83, 547 (2003).

20. Rice-Evans C.A., Miller N.J., Bolwell P.G., Bramley P.M., Pridham J.B.: Free Radic. Res. 22, 375 (1995). 
21. El-Meligy R.M., Awaad A.S., Soliman G.A., Kenawy S.A., Alqasoumi S.I.: Saudi Pharm. J. SPJ Off. Publ. Saudi Pharm. Soc. 25, 387 (2017).

22. Heo K.S., Lim K.T.: J. Med. Food 7, 349 (2004).

23. Suwalsky M., Ramírez P., Avello M., Villena F., Gallardo M.J. et al.: J. Membr. Biol. 249, 349 (2016).

24. Uchida K., Tomita H., Takemori T., Takamura H.: J. Food Sci. 82, 202 (2017).

25. Ganesan K., Sukalingam K., Xu B.: Antioxidants 6, 68 (2017).

26. Gutiérrez A.D.M., Bah M., Garduńo R.M.L., Mendoza D.S.O., Serrano C.V.: African J. Tradit. Complement. Altern. Med. 11, 259 (2014).

27. Doss A.: Anc. Sci. Life 29, 12 (2009).

28. Kajaria D.K., Gangwar M., Kumar D., Sharma A.K., Tilak R. et al.: Asian Pac. J. Trop. Biomed. 2, 905 (2012).

29. Nawab A., Thakur V.S., Yunus M., Ali Mahdi A., Gupta S.: Int. J. Mol. Med. 29, 277 (2012).

30. Chang J.J., Chung D.J., Lee Y.J., Wen B.H., Jao H.Y. et al.: J. Agric. Food Chem. 65, 9255 (2017).

31. Slamenova D., Kuboskova K., Horvathova E., Robichova S.: Cancer Lett. 177, 145 (2002).

32. Nieto M.A.V., Pérez Escandón B.E., Mendoza Pérez E., Lagunas V.M. Polibotánica 26, 137 (2008).

33. Bah M., Gutiérrez D., Escobedo C., Mendoza S, Rojas JI R. A.: Biochem. Syst. Ecol. 32, 197 (2004).

34. Hao L.J., Wang S., Zhu J.J., Wang Z.M., Wei S.H.: Zhongguo Zhong Yao Za Zhi 39, 2034 (2014).

35. Liu M.J., Yue P.Y.K., Wang Z., Wong R. N.-S.: Cancer Lett. 224, 229 (2005).

36. Bai Y., Qu X.Y., Yin J.Q., Wu L., Jiang H. et al.: Pharmacogn Mag. 10, 318 (2014).

37. Ehssan H.O.M., Abdalla O., Koko W., Saadabi A.M.: Int. J. Cancer Res. 10, 74 (2014).

38. Dzhambazov B., Daskalova S., Monteva A., Popov N.: Biol. Pharm. Bull. 25, 499 (2002).

39. Patel S.K.: Int. J. Pharm. Pharm. Sci. 1, 38 (2009).

40. Tai C.J., Wang C.K., Chang Y.J., Lin C.S., Tai C.J.: Evidence-Based Complement. Altern. Med. 2012, 10 pages (2012).

41. Tai C.J., Wang C.K., Tai C.J., Lin Y.F., Lin C.S. et al.: Evid. Based. Complement. Alternat. Med. 2013, 514719 (2013).
42. Son Y.O., Kim J., Lim J.C., Chung Y., Chung G.H. et al.: Food Chem. Toxicol. 41, 1421 (2003).

43. Lee K.-R., Kozukue N., Han J.-S., Park J.-H., Chang E.Y. et al.: J. Agric. Food Chem. 52, 2832 (2004).

44. Lee S.J., Oh P.S., Ko J.H., Lim K., Lim K.T.: Cancer Chemother. Pharmacol. 54, 562 (2004).

45. Ji Y.B., Gao S.Y., Ji C.F., Zou X.: J. Ethnopharmacol. 115, 194 (2008).

46. Li J., Li Q., Feng T., Li K.: Fitoterapia 79, 548 (2008).

47. Vieira P.M., Santos S.C., Chen-Chen L.: Braz. J. Biol. 70, 601 (2010).

48. Badami S., Manohara Reddy S.A., Kumar E.P., Vijayan P., Suresh B.: Phyther. Res. 17, 1001 (2003).

49. Gabrani R., Jain R., Sharma A., Sarethy I., Dang S. et al.: Indian J. Pharm. Sci. 74, 451 (2012).

50. Hsu S.C., Lu J.H., Kuo C.-L., Yang J.S., Lin M.W. et al.: Anticancer Res. 28, 1045 (2008).

51. Zhang S., Jiang C., Liu H., Guan Z., Zeng Q. et al.: Toxicol. Appl. Pharmacol. 271, 206 (2013).

52. Nzaramba M.N., Reddivari L., Bamberg J.B., Miller J.C.: J. Agric. Food Chem. 57, 8308 (2009).

53. García-Huertas P., Pabón A., Arias C., Blair S.: Biomédica 33 (Suppl 1) 33, 78 (2012).

54. Vijayan P., Vijayaraj P., Setty P.H.C., Hariharpura R.C., Godavarthi A. et al.: Biol. Pharm. Bull. 27, 528 (2004).

55. Munari C.C., de Oliveira P.F., Campos J.C.L., Martins S. de P.L., Da Costa J.C. et al.: J. Nat. Med. 68, 236 (2014).

56. Shiu L.Y., Chang L.C., Liang C.H., Huang Y.S., Sheu H.M. et al.: Food Chem. Toxicol. 45, 2155 (2007).

57. Wang H.-C., Chung P.-J., Wu C.-H., Lan K.-P., Yang M.-Y. et al.: J. Sci. Food Agric. 91, 178 (2011).

58. Ding X., Zhu F., Yang Y., Li M.: Food Chem. 141, 1181 (2013).

59. Li J., Li Q.-W., Gao D.-W., Han Z.-S., Li K.: Pharmazie 63, 534 (2008).

60. Ikeda T., Tsumagari H., Honbu T., Nohara T.: Biol. Pharm. Bull. 26, 1198 (2003).

61. Chakravarty A.K., Das B., Ali E., Pakrashi S.C.: J. Chem. Soc. Perkin Trans. 10, 467 (1984).

Received: 5.10 .2018 